TẠP CHÍ KHOA HỌC ĐẠI HỌC TÂN TRÀO
ISSN: 2354 - 1431

\title{
Những yếu tố ảnh hưởng đến thu hút khách du lịch của huyện Lâm Bình, tỉnh Tuyên Quang
}

Nguyễn Xuân Thiên ${ }^{a^{*}}$, Nguyễn Khải Hoàn ${ }^{b}$

${ }^{a}$ Truờng Đại học Kinh tế, Đại học Quốc gia Hà Nội

${ }^{b}$ Truò̀ng Đại học Tân Trào

"Email: thiennx@vnu.edu.vn

\section{Thông tin bài viết}

Ngày nhận bài:

05/6/2019

Ngày duyệt đăng:

$10 / 3 / 2020$

Tì khóa:

Yếu tố, ảnh hương, thu hút, khách du lịch, Lâm Bình, Tuyên Quang

\begin{abstract}
Tóm tắt
Huyện Lâm Bình, tỉnh Tuyên Quang được biết đến như một huyện có nhiều tiềm năng về phát triển du lịch. Trong những năm qua du lịch tỉnh Tuyên Quang nói chung và huyện Lâm Bình nói riêng đã có bước phát triển khá song thực sự chưa tương xứng với tiềm năng và lợi thế vốn có; Để góp phần đưa du lịch huyện Lâm Bình trở thành ngành kinh tế mũi nhọn: cần phải phân tích và nhận biết rõ các nhân tố ảnh hưởng đến thu hút khách du lịch đến với huyện Lâm Bình; từ đó để có chính sách phù hợp, kịp thời nhằm khai thác hiệu quả các tiềm năng và lợi thế vốn có. Bài báo sẽ đề cập và phân tích làm rõ những yếu tố ảnh hưởng đến thu hút khách du lịch của huyện Lâm Bình và đưa ra những gợi ý về mặt chính sách. Hy vọng sẽ góp phần thúc đẩy và phát triển bền vững ngành du lịch huyện Lâm Bình trong những năm tới.
\end{abstract}

\section{Bối cảnh và vấn đề}

Việt Nam nói chung và Tuyên Quang nói riêng đã xác định phương hướng phát triển là đưa du lịch trở thành ngành kinh tế mũi nhọn. Phương hướng này hoàn toàn đúng đắn; vừa phù hợp với xu thế phát triển của thế giới và điều quan trọng hơn là khai thác có hiệu quả các nguồn lực bao gồm nguồn lực tự nhiên, kinh tế - xã hội và văn hóa lịch sử. Trong những năm qua hòa chung với sự phát triển du lịch của cả nước; Du lịch Tuyên Quang đã có những bước phát triển mới. Với những tiềm năng và lợi thế vốn có về phát triển du lịch, khách du lịch đến Tuyên Quang có xu hướng tăng. " Kết quả thống kê 02 năm gần đây cho thấy: Năm 2017, tổng lươt khách du lịch đạt 1.590 .900 luợt, đạt 107\% kế hoạch năm, tăng 10,4\% so vơi năm 2016...Năm 2018, thu hút 1.760.600 luợt khách du lịch, đạt 105\% kế hoạch năm, tăng 10,7\% so với cùng kỳ năm trước" [3]. "Tổng thu xã hội tù du lịch đạt 2.936 tỷ đồng. Tạo việc làm cho khoảng 14.300 lao động ngành dịch vu du lịch"[1].
Con số này đối với Tuyên Quang là lớn nhưng mới chỉ bằng khoảng $25 \%$ so với tỉnh Phú Thọ (hàng năm tỉnh Phú Thọ thu hút khoảng 6-7 triệu lượt khách trong nước, chưa tính khách quốc tế). Để đưa du lịch trở thành ngành kinh tế mũi nhọn, Tuyên Quang bên cạnh đẩy mạnh thu hút du khách trong nước, đồng thời cũng cần phải đẩy mạnh thu hút khách nước ngoài. Trong số 7 huyện, thành phố của tỉnh Tuyên Quang thì Lâm Bình có nhiều điều kiện tự nhiên, xã hội và nhiều lợi thế để phát triển du lịch sinh thái và du lịch cộng đồng [8][9]. Theo thông tin mới nhất 6 tháng đầu năm 2019, Lâm Bình thu hút trên 23.000 lượt khách du lịch bao gồm cả khách nội địa và quốc tế [13][15].

Với những tiềm năng và lợi thế vốn có; và với hướng đi đúng, trong những năm qua Du lịch Tuyên Quang nói chung và huyện Lâm Bình nói riêng đã có bước phát triển. Khách du lịch đến Tuyên Quang cũng như Lâm Bình có xu hướng tăng. Tuy nhiên, so với tiềm năng và lợi thế thì kết quả đạt được còn rất khiêm tốn. Bằng cách nào để tăng cường thu hút khách du lịch đến Lâm Bình trong những năm tới (đến năm 
2025 và tầm nhìn đến năm 2030)? Việc phân tích và làm rõ các yếu tố ảnh hưởng đến thu hút khách du lịch của huyện Lâm Bình sẽ trả lời câu hỏi lớn nêu ra ở trên; đồng thời hy vọng sẽ góp phần đưa Du lịch Lâm Bình phát triển bền vững, sớm trở thành ngành kinh tế mũi nhọn.

\section{Nội dung nghiên cứu}

Đã có nhiều bài báo, bài giới thiệu, báo cáo về tình hình phát triển kinh tế-xã hội, báo cáo chuyên đề về phát triển du lịch Lâm Bình, Tuyên Quang phân tích tiềm năng, lợi thế của huyện Lâm Bình để phát triển du lịch trong đó có du lịch sinh thái, du lịch cộng đồng; đồng thời cũng cho thấy những kết quả đạt được, kế hoạch phát triển và những khó khăn hạn chế của huyện Lâm Bình trong phát triển du lịch [3; tr 8 15]. Tuy nhiên, vẫn còn thiếu những bài viết dưới góc độ học tập kinh nghiệm của nước ngoài và các địa phương khác của Việt Nam để vận dụng phân tích những yếu tố ảnh hưởng đến thu hút khách du lịch đặc biệt là khách du lịch quốc tế đến huyện Lâm Bình thuộc tỉnh Tuyên Quang. Để đưa du lịch trở thành ngành kinh tế mũi nhọn, phù hợp với tiềm năng và lợi thế của địa phương, Lâm Bình cần phải đẩy mạnh thu hút khách du lịch trong và ngoài nước; Do vậy, việc phân tích các yếu tố ảnh hưởng đến thu hút khách du lịch của huyện Lâm Bình là rất cần thiết và bổ ích.

2.1. Khung phân tích các yếu tố ảnh hưởng đến thu hút khách du lịch của huyện Lâm Bình tỉnh Tuyên Quang

Để hiểu rõ hơn các yếu tố tác động đến thu hút khách du lịch của huyện Lâm Bình, trước hết cần xác định rõ khung phân tích các yếu tố và quan hệ của các yếu tố ảnh hưởng đó. Khung phân tích này dựa trên nghiên cứu lý thuyết kết hợp với nghiên cứu thực tiễn, bao gồm các yếu tố bên ngoài và các yếu tố bên trong.

Trước hết phải bắt đầu từ mục tiêu phát triển của ngành du lịch Lâm Bình là trở thành ngành kinh tế mũi nhọn. Để đạt được mục tiêu này cần phải tăng cường thu hút khách du lịch nội địa và quốc tế đến Lâm Bình. Có như vậy mới tạo doanh thu lớn, hiệu quả cao và phát triển bền vững. Về mặt lý thuyết cũng như thực tiễn của các nước có ngành du lịch phát triển như Thái Lan, Ma-lai-xi-a, Singapore và nhiều nước khác đều cho thấy: Doanh thu từ ngành du lịch phụ thuộc rất lớn vào số lượt khách du lịch quốc tế đến tham quan du lịch và thời gian lưu trú. Tuy nhiên, dựa trên thực tiễn của Việt Nam và qua phân tích, khảo sát đặc điểm tự nhiên, xã hội và những lợi thế phát triển du lịch của huyện Lâm Bình, Tuyên Quang [3][9][15], chúng tôi đã đưa ra được khung phân tích các yếu tố ảnh hưởng đến thu hút khách du lịch của huyện Lâm Bình.

Xác định khung phân tích các yếu tố ảnh hưởng đến thu hút khách du lịch của huyện Lâm Bình được thể hiện qua sơ đồ 2.1 .

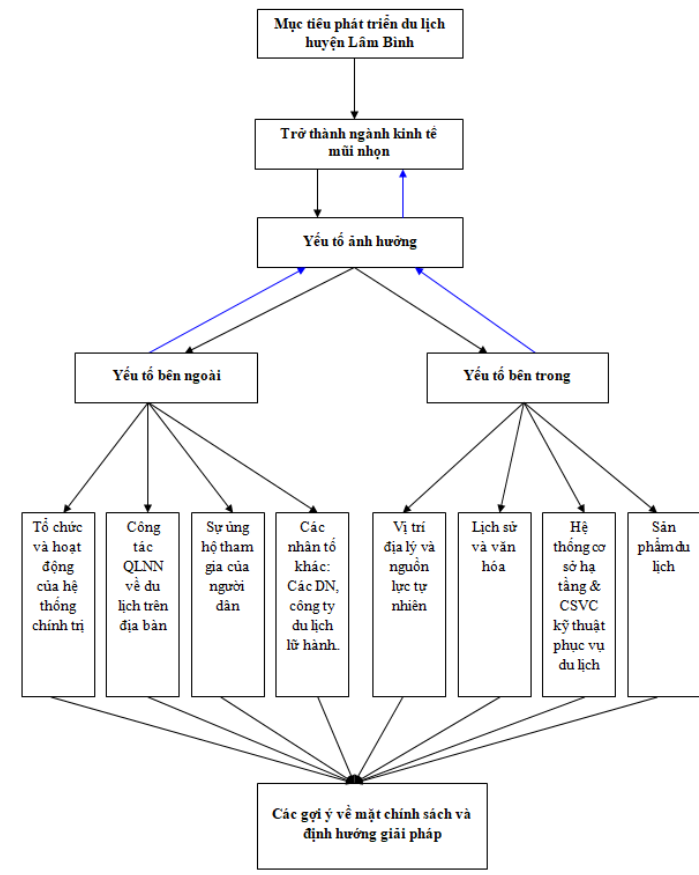

So đồ 2.1: Khung phân tích các yếu tố ảnh hưởng đến thu hút khách du lịch của huyện Lâm Bình

2.2. Các yếu tố ảnh huởng đến thu hút khách du lịch của huyện Lâm Bình

\subsubsection{Yếu tố bên ngoài}

Yếu tố bên ngoài có ảnh hưởng rất lớn đến dòng khách du lịch trong nước, quốc tế đến với Tuyên Quang nói chung và Lâm Bình nói riêng. Đó là các yếu tố bao gồm: (i) Tổ chức và hoạt động của hệ thống chính trị; (ii) Công tác QLNN về du lịch trên địa bàn; (iii) Sự ủng hộ, tham gia của người dân; (iv) Các nhân tố khác: các doanh nghiệp, công ty du lịch lữ hành, tổ chức, cá nhân... Để đón bắt các cơ hội phát triển và hạn chế mặt tiêu cực, vượt qua các thách thức cần phải nhận biết và hiểu rõ sâu sắc các yếu tố này.

\subsubsection{Tổ chức và hoạt động của hệ thống chính trị}

Nghị quyết 08-NQ/TW của Bộ Chính trị khóa XII đã xác định rõ quan điểm: "Phát triển du lịch là trách nhiệm của cả hệ thống chính trị, các cấp, các ngành, của toàn xã hội, có sụ lãnh đạo, chỉ đạo chặt chẽ của các cấp ủy đảng; phát huy mạnh mẽ vai trò động lục của doanh nghiệp và cộng đồng dân cu, sụ quản lý thống nhất của Nhà nuớc; tập trung nguồn lực quốc 
gia cho phát triển du lịch", Tổ chức và hoạt động của hệ thống chính trị chịu sự chi phối, tác động của rất nhiều yếu tố và có mối quan hệ chặt chẽ với nhau, khi một yếu tố thay đổi sẽ kéo theo các nhân tố khác thay đổi. Đó là các yếu tố như cơ cấu, tổ chức, chức năng của các cơ quan QLNN, hành chính, đội ngũ cán bộ, công chức, chế độ công vụ...

Vấn đề chủ yếu trong tổ chức và hoạt động của hệ thống chính trị ở địa phương là sự phân công trong nội bộ hệ thống tổ chức, việc xác định nhiệm vụ cho các cơ quan, đơn vị khác nhau để tạo được sự điều hoà, phối hợp cần thiết nhằm bảo đảm thực hiện được mục tiêu đưa du lịch trở thành ngành kinh tế mũi nhọn. Cơ cấu tổ chức hợp lý sẽ tránh được sự chồng chéo, vướng mắc, dễ dàng phối hợp, điều chỉnh công việc trong thực hiện nhiệm vụ, tiết kiệm thời gian; ngược lại nếu cơ cấu bất hợp lý sẽ làm giảm hiệu quả hoạt động, vì vậy cần thực hiện cải cách hành chính một cách đồng bộ, thiết thực, liên tục, tạo thuận lợi cho người dân và doanh nghiệp phát triển du lịch. Bộ máy hành chính là một chỉnh thể và mỗi cơ quan hành chính là một bộ phận, cả bộ máy chỉ hoạt động tốt khi mỗi bộ phận vừa thực hiện tốt nhiệm vụ của mình vừa phối hợp tốt với các bộ phận khác để hoàn thành được mục tiêu đặt ra.

\subsubsection{Công tác $\mathrm{QLNN}$ về du lịch trên địa bàn}

Lý thuyết quản lý nói chung và QLNN về du lịch nói riêng cho thấy: (i) Quản lý và chịu sự quản lý là tất yếu khách quan của bất cứ cá nhân và tổ chức nào trong mọi thể chế xã hội; (ii) Quản lý đúng đắn trở thành nhân tố quyết định sự thành công của mọi tổ chức, doanh nghiệp; (iii) Quản lý có trọng tâm, trọng điểm nhưng phải phù hợp với truyền thống và thông lệ quốc tế. Xuất phát từ tính đặc thù của hoạt động QLNN về du lịch, các kỹ năng cần thiết trong hoạt động công vụ được cụ thể hóa thành quy trình, quy phạm đòi hỏi phải được thực hiện một cách thống nhất. Ngoài việc công chức, viên chức phải tinh thông nghiệp vụ, nắm vững trình tự, thủ tục giải quyết công việc, tính chuyên nghiệp của công chức, viên chức còn thể hiện thông qua nhiều khía cạnh khác: khả năng ứng dụng CNTT, truyền thông, khả năng thích nghi, giao tiếp, hợp tác thông qua phối hợp nhóm, tổ, đội.

Cán bộ làm công tác tham mưu QLNN về du lịch trên địa bàn cần có kỹ năng, nghiệp vụ hành chính gắn với chuyên môn đào tạo và kinh nghiệm làm việc. Ngoài ra, văn hóa, đạo đức nghề nghiệp, ý thức tôn

${ }^{5}$ Nghị quyết số 08-NQ/TW ngày 16/01/2017 của Bộ Chính trị về phát triển du lịch trở thành ngành kinh tế mũi nhọn trọng và chấp hành kỷ luật, kỷ cương, việc gương mẫu thực hiện văn hóa công vụ là đòi hỏi khách quan, bắt nguồn từ tính chất của hoạt động quản lý, không chỉ là biểu hiện của đạo đức công vụ mà còn là thước đo tính chuyên nghiệp của cán bộ, công chức, viên chức. Để quản lý tốt hoạt động phát triển du lịch ở địa phương, cần trang bị đầy đủ tri thức về quản lý, nghiệp vụ quản lý cả về lý luận và thực tiễn cho các cán bộ quản lý từ cấp huyện đến cấp xã.

\subsubsection{Sự tham gia và ủng hộ của người dân}

Sự tham gia và ủng hộ của người dân trong phát triển du lịch đóng vai trò rất quan trọng và là nòng cốt trong phát triển sản phẩm du lịch tại địa phương. Người dân được đóng góp ý kiến, tham gia tích cực vào các hoạt động phát triển các sản phẩm du lịch, cung cấp nhân lực, vật lực cho doanh nghiệp du lịch, cung cấp thêm nhiều dịch vụ phục vụ cho khách du lịch tại địa phương. Người dân cũng có thể gián tiếp thực hiện việc QLNN thông qua việc tham gia vào hoạt động của các tổ chức xã hội, các hoạt động tự quản ở cơ sở. Thực tiễn cho thấy, sự tham gia, ủng hộ của người dân đối với hoạt động du lịch càng lớn thì hoạt động QLNN về du lịch càng dễ dàng đạt được mục tiêu và chỉ khi nào người dân thực sự đóng vai trò làm chủ trong quá trình hoạt động kinh doanh, phát triển du lịch, dịch vụ thì việc đưa du lịch trở thành ngành kinh tế mũi nhọn mới thực sự thành công.

Người dân tham gia quản lý hoạt động du lịch trên địa bàn sẽ đảm bảo tính khách quan, công bằng, dân chủ, thông qua đó giúp họ hiện thực hóa địa vị pháp lý cũng như thể hiện nguyện vọng chính đáng, phát huy vai trò làm chủ trong phát triển kinh tế du lịch tại địa phương. Người dân không chỉ có quyền giám sát đối với hoạt động của cơ quan hành chính nhà nước; tham gia giám sát việc thực hiện đầu tư phát triển sản phẩm du lịch của doanh nghiệp du lịch theo đúng quy định của pháp luật, chủ trương của chính quyền địa phương; thực hiện quyền khiếu nại, tố cáo mà còn có quyền tự mình tham gia vào hoạt động phát triển du lịch, trực tiếp thể hiện quyền lợi của mình; thực hiện nếp sống văn minh du lịch và có thái độ lịch sự, thân thiện, mến khách thể hiện trong đón tiếp, giao tiếp với khách du lịch. Bên cạnh đó, cần nâng cao ý thức bảo vệ tài nguyên, môi trường du lịch; giữ gìn và phát huy bản sắc văn hóa truyền thống, giữ gìn an ninh trật tự xã hội, bảo đảm an toàn cho khách du lịch.

2.2.1.4. Các nhân tố khác: các doanh nghiệp, công ty lữ hành du lịch và các dịch vụ du lịch khác 
Hoạt động của các doanh nghiệp, công ty lữ hành góp phần quảng bá thông tin điểm đến cho du khách, ảnh hưởng đến lựa chọn điểm đến của du khách và phối hợp với các dịch vụ khác: nhà hàng, khách sạn, nghỉ dưỡng, chăm sóc sức khỏe...tạo thành "gói” sản phẩm du lịch. Đồng thời, hoạt động của các doanh nghiệp lữ hành không chỉ ảnh hưởng đến truyền thông, góp phần nâng cao chất lượng du lịch mà còn liên quan đến các vấn đề bảo tồn văn hóa, bảo vệ tài nguyên môi trường. Vì vậy, hoạt động của các doanh nghiệp, công ty lữ hành có ảnh hưởng trực tiếp đến sự phát triển bền vững của du lịch.

Theo thống kê của Sở Văn hóa, Thể thao và Du lịch tỉnh Tuyên Quang, hiện toàn tỉnh có 288 cơ sở lưu trú với 2.950 phòng, 4.120 giường, trên 200 nhà hàng ẩm thực có quy mô lớn, 10 công ty lữ hành, vận chuyển du lịch phục vụ nhu cầu tham quan, giải trí tạo nên sự đa dạng, phong phú đối với các tour, tuyến du lịch. Trong đó, hoạt động chủ yếu đã được đa số doanh nghiệp lữ hành thực hiện là: thiết kế các tour du lịch thích hợp với từng nhóm du khách, đào tạo hướng dẫn viên, nhân viên có kiến thức cơ bản về nghiệp vụ du lịch, nhà hàng, khách sạn, bàn, buồng, bar...đồng thời, khuyến khích các hướng dẫn viên thường xuyên phát triển trình độ chuyên môn như tham gia các khóa đào tạo, hội thảo, tập huấn, bồi dưỡng chuyên môn, nghiệp vụ của các chuyên gia hoặc các tổ chức uy tín về kinh doanh, phát triển du lịch.

\subsubsection{Yếu tố bên trong}

Để một quốc gia hay một địa phương phát triển nhanh và bền vững: các cấp lãnh đạo và các nhà quản lý cũng như các doanh nghiệp cần phải biết khai thác tận dụng các nguồn lực (các yếu tố) từ bên ngoài; đồng thời phải sử dụng tốt, hiệu quả các yếu tố bên trong. Có thể nói các yếu tố bên ngoài có vai trò quan trọng; nhưng khai thác, sử dụng các yếu tố bên trong có vai trò quyết định đến sự phát triển kinh tế - xã hội nói chung và thu hút khách du lịch nói riêng. Trong phạm vi bài báo, chúng tôi chỉ đề cập và phân tích những yếu tố trực tiếp nội tại của huyện Lâm Bình có ảnh hưởng lớn đến thu hút du khách.

\subsubsection{Vị trí địa lý và nguồn lực tự nhiên}

“Huyện Lâm Bình ở vùng cao phía bắc tỉnh Tuyên Quang, diện tích tụ nhiên 78.152,17 ha; cách Hà Nội khoảng 280 km; cách thành phố Tuyên Quang khoảng 120 km; cách Cao nguyên đá Hà Giang khoảng 150 km; cách Hồ Ba Bể huyện Pác Nặm, tỉnh Bắc Kạn khoảng $130 \mathrm{~km}$ và cách hồ Núi Cốc tỉnh Thái Nguyên 180 km" [9]. Với vị trí địa lý của Lâm Bình có thể kết nối với các Trung tâm du lịch của Bắc Kạn, Thái Nguyên, Hà Giang và thành phố Hà Nội. Và từ thành phố Hà Nội lan tỏa ra trong và ngoài nước.

"Là huyện vùng sâu, vùng xa, vùng cao của tỉnh Tuyên Quang, địa hình bị chia cắt bởi nhiều dãy núi cao mà chủ yếu là núi đá vôi và khe sâu; độ che phủ rùng chiếm trên $75 \%$ (Diện tích rùng tụ nhiên: 58.870,18ha, trong đó: Rùng phòng hộ 39.028,72ha, rùng sản xuất 18.972,96ha); các khu rùng nguyên sinh có hệ động vật, thục vật đa dạng, phong phú, trong đó có nhiều loài quý hiếm nhu: Pơ Mu, Thông tre, Thông đỏ, Nghiến, Trai lý, Đinh, Sến, Dổi, các loài Lan Kim tuyến và một số loài duợc liệu quý (cây một lá, Thất diệp nhất chi hoa,...); Động vật có: Voọc đen má trắng, Vươn, Khỉ, Hưou, Lợn rùng, Mèo rùng, Cu li, Sóc, Cầy, Nhím,... Tù̀ đó tạo nên nhũng cung đưòng, nhũng dãy núi, nhũ̃ng thung lũng có cảnh quan thiên nhiên hùng vĩ, kỳ thú tuyệt đẹp"[9].

Có thể nói cảnh quan thiên nhiên núi rừng của Lâm Bình đẹp tuyệt vời, hùng vĩ, có nhiều danh lam thắng cảnh nổi tiếng, đan xen giữa rừng và hồ nước, non nước hữu tình; đây có thể coi là lợi thế tuyệt đối của Lâm Bình để thu hút du khách, đặc biệt là du khách quốc tế. Với vị trí địa lý của Lâm Bình, việc di chuyển từ các trung tâm du lịch, và các thành phố lớn như Hà Nội đến Lâm Bình cũng là thuận lợi.

Ngoài các lợi thế tuyệt đối vốn có như sở hữu các nguồn lực tự nhiên, Lâm Bình còn có lợi thế tương đối như chi phí sinh hoạt (lưu trú và các chi tiêu khác) là rẻ tương đối so với các trung tâm du lịch khác.

\subsubsection{Lịch sử và văn hóa}

Lâm Bình là một huyện vùng cao của tỉnh Tuyên Quang; là nơi lưu giữ những giá trị văn hóa truyền thống đặc sắc của các dân tộc. "Huyện có 08 đơn vị hành chính cấp xã, 76 thôn, bản; dân số trên 33 nghìn người với trên 12 dân tộc cùng chung sống, dân tộc thiểu số chiếm trên 95\%, trong đó: Dân tộc Tày chiếm 62\%, Dao trên 25\%, Mông 6\%, PàThẻn 2\%, còn lại là các dân tộc khác. Đặc biệt, tại thôn Thuợng Minh, xã Hồng Quang, huyện Lâm Bình có tộc nguời Thủy hiện còn 54 hộ, 105 khẩu. Là tộc người ở Việt Nam có duy nhất ở huyện Lâm Bình, tỉnh Tuyên Quang" [9]. Có thể nói: Lâm Bình là một trong các địa phương hội tụ bản sắc văn hóa của đồng bào dân tộc thiểu số và có nét văn hóa độc đáo, có các lễ hội đặc trưng mà các địa phương khác không thể có được; như Nghi lễ Nhảy lửa huyền bí của dân tộc Pà Thẻn...

Hoạt động kinh doanh, phát triển du lịch trên địa bàn luôn mang tính kế thừa và chịu sự tác động của 
các yếu tố xã hội như văn hóa, lịch sử, truyền thống, tập quán, thói quen. Sự tác động của các yếu tố này luôn bao hàm cả hai khả năng tích cực và tiêu cực. Vấn đề đặt ra là phải biết kế thừa, vận dụng, phát huy các yếu tố tích cực, nhất là các giá trị lịch sử, văn hóa, truyền thống đã được kết tinh qua nhiều thời kỳ và hạn chế những yếu tố tiêu cực, lạc hậu làm ảnh hưởng tới việc phát triển du lịch và gìn giữ văn hóa, bản sắc dân tộc ở địa phương, nơi có những lợi thế về phát triển du lịch.

2.2.2.3. Hệ thống hạ tầng và cơ sở vật chất kỹ thuật phục vụ du lịch

Đảng và nhà nước đã xác định du lịch là một ngành kinh tế dịch vu tổng hợp, có tính liên ngành, liên vùng, xã hội hóa cao và mang nội dung văn hóa sâu sắc ${ }^{6}$. Do vậy hệ thống cơ sở hạ tầng và cơ sở vật chất kỹ thuật phục vụ du lịch không chỉ bao gồm các yếu tố riêng của ngành du lịch mà bao gồm cả các yếu tố của các ngành khác được huy động vào hoạt động nhằm tạo ra sản phẩm và dịch vụ du lịch thỏa mãn nhu cầu của con người. Với nội hàm đó có thể thấy rằng hạ tầng và cơ sở vật chất kỹ thuật phục vụ du lịch, đặc biệt là thu hút du khách quốc tế đến Việt Nam nói chung và Lâm Bình, Tuyên Quang nói riêng đã được đầu tư phát triển khá; nhưng so với yêu cầu thì vẫn còn thiếu và còn hạn chế. Du khách nước ngoài đến Hà Nội, Việt Nam bằng đường hàng không rất thuận lợi; nhưng tuyến đường từ Hà Nội đi Lâm Bình, Tuyên Quang tuy đã được đầu tư nâng cấp, nhưng vẫn còn hạn chế. Cơ sở hạ tầng (đường giao thông) đến các điểm, các khu du lịch chưa được xây dựng một cách đồng bộ.

Hệ thống khách sạn, nhà hàng, các khu vui chơi giải trí, phương tiện vận chuyển... và đặc biệt bao gồm các công trình kiến trúc bổ trợ đã được đầu tư xây dựng nhưng chưa thật sự gắn kết, hiện đại và sầm uất có tầm quy mô lớn. Thiết nghĩ, nếu khách du lịch quốc tế đến Lâm Bình với tốc độ tăng và nghỉ dưỡng dài ngày thì rất khó có thể đáp ứng được! Tuyên Quang cũng chưa có những khu vui chơi giải trí có tên tuổi đa dạng, phong phú, nhộn nhịp, quy mô lớn như một số tỉnh (thành phố) của Việt Nam đã đầu tư xây dựng. Để thu hút khách du lịch quốc tế nhằm thỏa mãn nhu cầu vui chơi giải trí; nên chăng Tuyên Quang nói chung và Lâm Bình nói riêng cũng cần phải đầu tư xây dựng các khu vui chơi giải trí có tầm cỡ quốc gia.

\subsubsection{Sản phẩm du lịch}

\footnotetext{
${ }^{6}$ Nghị quyết số 08-NQ/TW ngày 16/01/2017 của Bộ Chính trị về phát triển du lịch trở thành ngành kinh tế mũi nhọn
}

Như mục 2.1. đã chỉ ra: một trong những yếu tố ảnh hưởng lớn, hấp dẫn, thu hút lượng khách du lịch quốc tế đến Thái Lan, Ma-lai-xi-a cùng nhiều nước và các thành phố khác trên thế giới là do các nước và các thành phố này đã có nhiều sản phẩm du lịch đa dạng, phong phú, độc đáo và khác biệt. Để góp phần tăng nhanh lượng khách du lịch quốc tế đến Lâm Bình; vấn đề rất cần là phải xây dựng đầu tư ra các sản phẩm du lịch độc đáo và khác biệt phù hợp với tiềm năng và thế mạnh của địa phương. Sản phẩm du lịch bao gồm $c a ̉$ yếu tố hũu hình và nhũng yếu tố vô hình. Yếu tố hưu hình là hàng hóa, yếu tố vô hình là dịch vu vui chơi, giải trí.

Thế mạnh và điểm nổi bật của Lâm Bình là sản phẩm vô hình (văn hóa phi vật thể) độc đáo, khác biệt của đồng bào các dân tộc thiểu số, như: Nghi lễ Nhảy lưa huyền bí của dân tộc Pà Thẻn, Bơi thuyền Kayak trên hồ Lâm Bình, Tuyên Quang; chiêm ngương nhũng cảnh đẹp thiên nhiên ban tặng với nhũng cánh rù̀ng nguyên sinh, nhũng hang động kỳ ảo và nhũng thác nước tuôn trào...thưởng thức các làn điệu dân ca: hát Then, hát Páo dung, hát cọi, múa khèn,...Đây là điều kiện thuận lợi để phát triển du lịch cộng đồng.

Những lễ hội và các dịch vụ vui chơi giải trí hiện nay của Lâm Bình là rất quí, phù hợp với tiềm năng và lợi thế của đồng bào các dân tộc; Tuy nhiên để thu hút du khách trong và ngoài nước đến Lâm Bình nhiều hơn nữa, cần phải tạo ra những sản phẩm hàng hóa và dịch vụ, vui chơi giải trí, thư giãn độc đáo và phong phú hơn; cần có những sản phẩm và dịch vụ đặc biệt mà chỉ có Lâm Bình mới có.

\subsection{Một số gọi ý về mặt chính sách và định hướng giải pháp đối với huyện Lâm Bình}

2.3.1. Định huớng chính sách và nhận thức của người dân

Khi tiến hành xây dựng chính sách và định hướng nhận thức của người dân cần đặt ra các câu hỏi lớn: (i) Địa phương phải ban hành những chính sách gì? Và phải thực thi các giải pháp gì để đạt được mục tiêu đề ra? Mỗi giải pháp phải được định lượng cụ thể, chỉ rõ trách nhiệm thực hiện và chế tài thực hiện chứ không chỉ mang tính nguyên tắc, chung chung; (ii) Địa phương lấy nguồn lực ở đâu và huy động các nguồn lực như thế nào để hiện thực hóa mục tiêu? Khi nghiên cứu phương án huy động nguồn lực tài chính rất cần xác định rõ nhu cầu làm thế nào để thu hút vốn đầu tư ngoài địa phương gắn với nhu cầu thu hút công nghệ và nhất là thu hút vốn FDI? 
Định hướng chính sách, kế hoạch phát triển của chính quyền cấp huyện và nhận thức của người dân là quan trọng nhưng cần có sự hỗ trợ quan tâm giúp đỡ từ các cấp các ngành. Vì du lịch là một ngành kinh tế tổng hợp, để ngành du lịch "cất cánh" và phát triển, cần có sự quan tâm, phối hợp giữa các ngành, các cấp từ nhận thức đến kinh doanh du lịch. Để du lịch Lâm Bình phát triển bền vững cần phải đầu tư nhằm tăng cường thu hút khách du lịch trong nước và quốc tế; có như thế du lịch Lâm Bình mới trở thành ngành kinh tế mũi nhọn; đóng góp quan trọng cho phát triển kinh tế xã hội của địa phương.

Xây dựng và ban hành các chính sách, đề án bảo tồn di sản văn hóa gắn với phát triển du lịch. Xây dựng cơ chế ưu đãi, hỗ trợ và ưu tiên sử dụng ngân sách cho các hoạt động bảo vệ môi trường du lịch và đào tạo phát triển nguồn nhân lực du lịch: "Để phát triển kinh tế, xã họi $i$ xóa đói, giảm nghèo cho đồng bào dân tộc thiểu số trên nguyên tắc phát huy, bảo tồn và bền vũung nhũng giá trị thiên nhiên, bản sắc văn hóa dân tộc. Chính quyền và nhân dân các dân tộc huyện Lâm Bình, tỉnh Tuyên Quang luôn xác định nhũng đặc điểm nổi bật trên là một lợi thế để phát triển $d u$ lịch và ưu tiên phát triển du lịch cộng đồng"[9].

Với định hướng chính sách và nhận thức đúng đắn của Chính quyền và nhân dân các dân tộc huyện Lâm Bình như đã chỉ ra ở trên; chúng tôi tin rằng hoạt động du lịch của Lâm Bình sẽ phát triển vững chắc và bền vững trong những năm tới.

\subsubsection{Coi trọng chính sách sản phẩm}

Theo nhận xét của các chuyên gia kinh tế cũng như của các du khách nước ngoài khi đến Tuyên Quang, cho thấy: sản phẩm du lịch còn nghèo nàn, đơn giản, chưa thể hiện được đặc trưng văn hóa vùng, miền. Sản phẩm du lịch cho du khách theo hai nghĩa: sản phẩm hữu hình và sản phẩm dịch vụ (vô hình). Để tạo ra các sản phẩm du lịch đặc trưng, Lâm Bình phải đầu tư, đặc biệt phải có chính sách thu hút các nhà đầu tư trong và ngoài nước vào các khu du lịch, các dịch vụ mua sắm, vui chơi giải trí trên địa bàn tỉnh và tại huyện Lâm Bình. Cần có những sản phẩm du lịch đặc trưng, độc đáo để tạo ấn tượng sâu sắc cho du khách với những giá trị vật chất và tinh thần, phù hợp với lợi thế và tiềm năng thế mạnh vốn có của Lâm Bình. Đồng thời xây dựng, khai thác sản phẩm du lịch gắn liền với sản phẩm đặc trưng của vùng du lịch miền núi phía Bắc là du lịch văn hóa, sinh thái, tâm linh, gắn với tìm hiểu bản sắc văn hóa các dân tộc thiểu số lấy du lịch cộng đồng và du lịch sinh thái làm trung tâm.

Hỗ trợ kinh phí về đào tạo lao động địa phương làm việc trong doanh nghiệp; xây dựng chính sách ưu đãi tín dụng và huy động vốn; hỗ trợ kinh phí đầu tư cho cá nhân, tổ chức kinh tế tham gia vào sản xuất sản phẩm lưu niệm phục vụ khách du lịch và tạo ra sản phẩm mới mang tính đặc trưng của Lâm Bình, Tuyên Quang; hỗ trợ các hoạt động xúc tiến thương mại và quảng bá sản phẩm trên các trang thông tin điện tử của tỉnh và của ngành du lịch. Khuyến khích các doanh nghiệp, các công ty du lịch đầu tư sản xuất kinh doanh các sản phẩm du lịch gắn với truyền thuyết và đời sống sinh hoạt của đồng bào các dân tộc. Gợi ý và định hướng: (i) Doanh nghiệp, công ty nên và cần làm sản phẩm gì, với khối lượng bao nhiêu và làm như thế nào hoặc bằng cách gì hay bằng công nghệ nào? Và ai làm, làm khi nào? Tiêu thụ ở đâu? Khi xác định câu hỏi này và tìm cách trả lời nó thì phải xác định được nhu cầu phát triển doanh nghiệp trên địa bàn; (ii) Địa phương làm cái đó hay lấy sản phẩm đó ở đâu? Tổ chức sản xuất ra sao? Tổ chức theo chuỗi giá trị sản phẩm hay tổ chức theo cụm liên kết lãnh thổ như thế nào?

\subsection{3. Đầu tư xây dưng kết cấu ha tầng}

Trong những năm qua, thực trạng kết cấu hạ tầng của Việt Nam nói chung và Tuyên Quang nói riêng đã có bước phát triển do chính sách và giải pháp đầu tư đúng đắn của Nhà nước, của tỉnh; nhưng so với yêu cầu cho phát triển du lịch trong bối cảnh mới thì còn nhiều hạn chế. Con số ấn tượng trong năm 2017 là Việt Nam đã thu hút gần 13 triệu lượt du khách quốc tế; năm 2018 đón 15.497.791 lượt người [5]; dự báo trong những năm tới khách du lịch quốc tế sẽ đến Việt Nam tăng lên. Theo số liệu đã được công bố trên địa bàn tỉnh Tuyên Quang "Hiện có 288 cơ sở luu trú, hơn 200 nhà hàng ẩm thực có quy mô lớn; 10 công ty lũ hành; hai điểm du lịch đạt tiêu chuẩn cấp biển hiệu phục vu khách du lịch; dịch vu vận chuyển khách $d u$ lịch đã có sụ tham gia của doanh nghiệp, cá nhân trong và ngoài tỉnh"[1]; Trong số này huyện Lâm Bình có bao nhiêu cơ sở ? số phòng đạt tiêu chuẩn của khách sạn 3 sao trở lên là bao nhiêu? Cơ hội đang đến, do vậy, Lâm Bình cần phải ưu tiên đầu tư để xây dựng kết cấu hạ tầng du lịch phù hợp với quy hoạch đã được các cấp có thẩm quyền phê duyệt. Vấn đề là Lâm Bình cần phải từng bước hiện đại hóa cơ sở lưu trú. Cảnh quan thiên nhiên, tài nguyên du lịch là quan trọng; nhưng cơ sở lưu trú cũng không kém phần quan trọng; 
Người Việt Nam có câu: "Một đêm nằm bằng một năm ơ". Vì nơi nghỉ ngơi có tốt, thì khách du lịch mới ở lâu. Cơ sở kinh doanh du lịch mới có nguồn thu. Đa dạng hóa các loại hình dịch vụ, đảm bảo hệ thống cơ sở lưu trú đủ tiện nghi hội nghị, hội thảo, phòng họp, phòng tiệc, phục vụ ăn nhanh, dịch vụ chăm sóc sức khỏe...với chất lượng dịch vụ cao. Đổi mới phương thức và phong cách phục vụ, nâng cao trình độ công nghệ phục vụ.

\subsubsection{Phát triển nguồn nhân lực}

Nguồn nhân lực du lịch có chất lượng cao là yếu tố cực kỳ quan trọng để đạt năng lực cạnh tranh cao của điểm đến $\mathrm{du}$ lịch nói chung và mỗi doanh nghiệp du lịch nói riêng. Để đào tạo và xây dựng được nguồn nhân lực phù hợp với yêu cầu phát triển du lịch và hội nhập quốc tế, huyện Lâm Bình cần:

- Rà soát đội ngũ cán bộ, nhân viên, người lao động trong ngành du lịch; phân loại trình độ để có kế hoạch đào tạo và bỗi dưỡng về chuyên môn và ngoại ngữ, nhằm đáp ứng nhu cầu trước mắt và những năm tới.

- Tổng kết đánh giá về mô hình du lịch cộng đồng tại 04 điểm: thôn Nà Tông, Nà Đông (xã Thượng Lâm), thôn Nà Muông (xã Khuôn Hà) và thôn Nặm Đíp (xã Lăng Can). Từ tổng kết mô hình du lịch cộng đồng: rút ra những điểm mạnh, điểm yếu và hạn chế, nguyên nhân cần khắc phục.

- Ngoài bỗi dưỡng kiến thức cho các hộ gia đình làm du lịch cộng đồng, huyện cần quan tâm bồi dưỡng lực lượng lao động trẻ gửi đi đào tạo tại các cơ sở giáo dục đại học, cơ sở giáo dục nghề nghiệp về kinh doanh du lịch để đón bắt nhu cầu khách du lịch đến Lâm Bình trong những năm tới; đồng thời đây là lực lượng chủ chốt trong hệ thống kinh doanh dịch vụ du lịch của huyện Lâm Bình.

\subsubsection{Phát triển hợp tác và liên kết vùng trong kinh doanh du lich}

Để thúc đẩy và tăng cường thu hút khách du lịch trong nước và quốc tế đến với Lâm Bình là phải đẩy mạnh hợp tác và liên kết với các tỉnh, thành trong cả nước trên tinh thần vì lợi ích chung; từ đó có cơ sở mở rộng hợp tác quốc tế để thu hút du khách. Thị trường khách quốc tế có được mở rộng và tăng lên hay không? Điều đó phụ thuộc rất nhiều vào sự hợp tác với các tỉnh miền núi phía Bắc và với các tỉnh, thành phố trong phạm vi cả nước. Lâm Bình phải trở thành một điểm đến quan trọng trong chuỗi giá trị của các công ty kinh doanh du lịch trong nước và quốc tế.
Ngoài ra Du lịch Lâm Bình cũng cần mở rộng liên kết, hợp tác với các công ty du lịch lữ hành ở các tỉnh/thành phố khác trong cả nước. Điều đó sẽ góp phần tăng lượng khách du lịch đến với Lâm Bình.

Chính quyền địa phương cần hỗ trợ khởi nghiệp trong kinh doanh phát triển du lịch trên địa bàn. Cụ thể, cần tổ chức các cuộc thi sáng tạo, ý tưởng kinh doanh để các cá nhân, tập thể có động lực, có môi trường thúc đẩy sự sáng tạo và dần hình thành ý tưởng kinh doanh, phát triển các dịch vụ du lịch. Ngay cả các doanh nghiệp khách sạn, nhà hàng hay công ty lữ hành đều có thể tổ chức các cuộc thi sáng tạo nhằm cải thiện chất lượng dịch vụ tại các cơ sở kinh doanh đó. Từ đó, có thể khai thác được các ý tưởng kinh doanh dựa trên các góc nhìn khác nhau và lựa chọn các ý tưởng kinh doanh khả thi để thực hiện và cải thiện chất lượng dịch vụ, hiệu quả kinh doanh.

2.3.6. Tăng cưòng và hỗ trợ công tác xúc tiến quảng bá du lịch

Lâm Bình có cảnh quan thiên nhiên đẹp tuyệt vời, hiếm có: núi non, hồ, thác, rừng nguyên sinh hòa quyện với nhau gắn liền với cuộc sống của đồng bào các dân tộc thiểu số với những bản sắc văn hóa độc đáo và với những dịch vụ vui chơi giải trí mang đậm dấu ấn của đồng bào dân tộc thiểu số. Lâm Bình có rất nhiều tiềm năng và lợi thế để phát triển du lịch sinh thái gắn với du lịch cộng đồng. Mặt khác Lâm Bình là một bộ phận của tỉnh Tuyên Quang- một tỉnh có rất nhiều tiềm năng và lợi thế để phát triển du lịch. Như vậy, Lâm Bình lại càng có điều kiện thuận lợi để phát triển các loại hình du lịch. Trong những năm qua khách du lịch đến Lâm Bình hàng năm có xu hướng tăng; nhưng so với tiềm năng và lợi thế vẫn còn rất khiêm tốn. Nguyên nhân thì có nhiều; nhưng một trong những lý do là công tác xúc tiến quảng bá du lịch cho du khách nước ngoài của Việt Nam nói chung và Tuyên Quang nói riêng còn chưa tương xứng với tiềm năng và lợi thế để phát triển. Vì vậy, cơ quan quản lý du lịch Tuyên Quang nói chung và Lâm Bình nói riêng cần đóng một vai trò tích cực hơn trong công tác xúc tiến quảng bá du lịch. Về vấn đề này, Lâm Bình ngoài tích cực chủ động quảng cáo hình ảnh: tài nguyên du lịch, chương trình, lễ hội qua các kênh truyền thông của tỉnh; đồng thời năng động phối hợp với Hiệp hội Du lịch Việt Nam và Tổng cục Du lịch Việt Nam để quảng cáo về Du lịch Lâm Bình và xúc tiến tìm kiếm thị trường du lịch.

Chúng ta còn thiếu tính tổ chức về các chương trình hỗ trợ doanh nghiệp tiếp cận với các nguồn tài 
trợ. Hầu hết các doanh nghiệp trên địa bàn đều phải tự xoay xở nguồn vốn, trong khi đó tại các quốc gia phát triển...họ tổ chức rất bài bản và thành công trong việc khai thác ý tưởng kinh doanh, xúc tiến quảng bá du lịch, cung cấp vốn đầu tư, chia sẻ kinh nghiệm kinh doanh từ các cố vấn chuyên môn để giúp cho các doanh nghiệp khởi nghiệp thành công. Rõ ràng, việc hỗ trợ các doanh nghiệp khởi nghiệp không chỉ cần vốn mà họ cần được tư vấn từ các chuyên gia, do vậy cần phải thiết lập mạng lưới các nhà cố vấn, chuyên gia để giúp cho doanh nghiệp khởi nghiệp.

\section{Kết luận}

Trong những năm gần đây Du lịch Lâm Bình đã có những bước phát triển khá tốt. Khách du lịch đến Lâm Bình có xu hướng tăng. Tuy nhiên so với tiềm năng và lợi thế vốn có, thì kết quả đạt được vẫn còn khiêm tốn. Việc tăng cường thu hút khách du lịch nội địa và quốc tế đến với Tuyên Quang nói chung và Lâm Bình nói riêng chịu ảnh hưởng nhiều yếu tố: nhóm yếu tố bên ngoài và nhóm yếu tố bên trong. Nhìn chung các yếu tố bên ngoài đang tạo ra nhiều cơ hội cho du lịch Lâm Bình cũng như Du lịch Tuyên Quang phát triển nhưng cũng đặt ra không ít thách thức. Nhóm yếu tố bên trong (nội tại) có ảnh hưởng lớn và đóng vai trò quyết định; những yếu tố nổi trỗi đó là: vị trí địa lý và nguồn lực tự nhiên, lịch sử và văn hóa, hệ thống hạ tầng và cơ sở vật chất kỹ thuật phục vụ du lịch và sản phẩm du lịch. Các lợi thế này, bao gồm cả lợi thế tuyệt đối và lợi thế so sánh. Kết hợp tham khảo kinh nghiệm quốc tế và một số địa phương trong cả nước như tỉnh Phú Thọ, Hà Giang và Thái Nguyên. Báo cáo rút ra một số điểm mạnh và hạn chế của các yếu tố làm ảnh hưởng đến thu hút du khách đặc biệt là du khách quốc tế của huyện Lâm Bình; từ kết quả nghiên cứu, báo cáo đưa ra 6 gợi ý về mặt chính sách nhằm tăng cường thu hút khách du lịch đến với Lâm Bình trong những năm tới; để góp phần đưa Du lịch Lâm Bình phát triển bền vững, sớm trở thành ngành kinh tế mũi nhọn./.

\section{TÀI LIỆU THAM KHẢO}

1. Baonhandan.vn, Thứ Bảy, ngày 31/8/2019, Tuyên Quang tập trung phát triển du lịch, Hải Chung.

2. Bộ Văn hóa, Thể thao và Du lịch (2012): Chiến lược phát triển du lịch Việt Nam đến năm 2020, tầm nhìn đến năm 2030, Hà Nội. Nguyễn Khải Hoàn, Nguyễn Phương Thảo, Nguyễn Văn Hiền (2018), Phát triển du lịch sinh thái ở Tuyên Quang: Nghiên cưu truờng hợp huyện Lâm Bình, Tạp chí Khoa học, Đại học Tân Trào, số 10 tháng 12/2018.

4. Nguyễn Xuân Thiên (2018), Nhũ̃ng yếu tố ảnh hưởng đến thu hút khách du lịch quốc tế của tỉnh Phú Thọ, Hội thảo khoa học quốc gia: Phát triển kinh tế địa phương: Cơ hội, thách thức và định hướng phát triển trong bối cảnh toàn cầu hóa và cuộc cách mạng công nghiệp 4.0, tập II, NXB Lao Động.

5. Tổng cục Du lịch Du lịch Việt Nam năm 2018 qua các con số, Vietnamtourism.gov.vn/index.php /items/29932

6. Top global destination cities in 2013, Forbes.com.

7. UNWTO, 2014. Tourism Highlights 2013 Edition.

8. Ủy ban nhân dân tỉnh Tuyên Quang (2019), Báo cáo sơ kết 2 năm thực hiện Nghị quyết số 08NQ/TW ngày 16/01/2017 của Bộ Chính trị về phát triển du lịch trở thành ngành kinh tế mũi nhọn.

9. Ủy ban nhân dân huyện Lâm Bình (2017), Một số tình hình về du lịch cộng đồng (homestay) huyện Lâm Bình, tỉnh Tuyên Quang.

10. Ủy ban nhân dân huyện Lâm Bình (2016), Báo cáo kết quả thực hiện nhiệm vụ phát triển kinh tế-xã hội năm 2016; kế hoạch phát triển kinh tế-xã hội năm 2017.

11. Ủy ban nhân dân huyện Lâm Bình (2017), Báo cáo kết quả thực hiện nhiệm vụ phát triển kinh tế-xã hội, quốc phòng-an ninh năm 2017; phương hướng, mục tiêu và giải pháp phát triển kinh tế-xã hội, quốc phòng-an ninh năm 2018.

12. Ủy ban nhân dân huyện Lâm Bình (2018), Báo cáo kết quả thực hiện nhiệm vụ phát triển kinh tế-xã hội, quốc phòng-an ninh năm 2018; phương hướng, mục tiêu và giải pháp phát triển kinh tế-xã hội, quốc phòng-an ninh năm 2019.

13. Sở Văn hóa, Thể thao và Du lịch Tuyên Quang (2019), Báo cáo tình hình phát triển kinh tế du lịch ở nông thôn trên địa bàn tỉnh.

14. Ủy ban nhân dân tỉnh Tuyên Quang (2011), Quy hoạch tổng thể phát triển du lịch tỉnh Tuyên Quang đến năm 2020, định hướng đến năm 2030

15. Lambinh.tuyenquang.gov.vn/tin-tuc-sukien/trang-6.html 


\section{Factors affecting tourist attraction in Lam Binh district, Tuyen Quang province}

Nguyen Xuan Thien, Nguyen Khai Hoan

\section{Article info}

Recieved:

05/6/2019

Accepted:

$10 / 3 / 2020$

Keywords:

Factors; influence; attraction; tourist; Lam Binh; Tuyen Quang.

\begin{abstract}
Lam Binh district, Tuyen Quang province is known as a district with great potential for tourism development. In recent years, tourism in Tuyen Quang province in general and Lam Binh district in particular has had good development, but not really commensurated with the inherent potential and advantages; In order to contribute to bringing Lam Binh tourism into a key economic sector: it is necessary to analyze and identify clearly the factors affecting tourist attraction to Lam Binh district to have appropriate and timely policies in order to effectively exploit the inherent potentials and advantages. The article will discuss and analyze clearly the factors affecting tourism attraction of Lam Binh district and make policy suggestions. Hoping to contribute to the promotion and sustainable development of Lam Binh tourism industry in the coming years.
\end{abstract}

